\title{
College and research libraries
}

\section{and IFLA}

\author{
By Robert Maloy \\ Director of Libraries \\ Smithsonian Institution
}

\section{The work of the University Libraries and Other General Research Libraries Section.}

$\mathbf{T}$ institutions (IFLA) is an international library organization comprising eight large Divisions subdivided into 31 professional Sections; further, there are ten Round Tables, and six distinct and major Core Programs. Its members and affiliates at the end of 1984 were 1,182 from 121 countries. Full complexity and range of content, methods and responsibilities of librarianship on the current international information scene are represented. Although IFLA as the general voice of librarianship is independent of UNESCO, nevertheless, because of UNESCO's major role in information issues, IFLA closely follows UNESCO work and indeed has performed contracts for UNESCO in such areas as universal bibliographic control, training, national libraries, libraries for the blind, etc. In 1984, 19.2\% of IFLA resources came from UNESCO.

\section{Academic and research libraries and IFLA}

ACRL's interests are represented in IFLA through the association membership held by the American Library Association and through institutional memberships held by individual libraries, library schools, bibliographic and research institutes, e.g., the University of Illinois at Chicago.
The Association of Research Libraries is also an association member.

IFLA is organized for the broad interests of its general membership into eight Divisions ${ }^{1}$. Obviously there are overlaps among Divisions; however, concerns of ACRL members are dealt with mainly in the General Research Libraries Division, in which group are large, general academic and research libraries, national libraries, the central or integrated library systems of universities, and the parliamentary libraries, e.g., Library of Congress, because the latter serve as general research libraries. The General Research Libraries Division is further divided into three Sections ${ }^{2}$, and ACRLtype work is done in the University Libraries and Other General Research Libraries Section. Here the objective is the development of models for academic and research library service with a particular eye for uniform bibliographic control, professional education, and the effectiveness of technology. Within recent years the Section has

\footnotetext{
${ }^{1}$ General Research Libraries, Special Libraries, Libraries Serving the General Public, Bibliographic Control, Collections and Services, Management and Technology, Education and Research, Regional Activities.

${ }^{2}$ National Libraries, University Libraries and Other General Research Libraries, Parliamentary Libraries.
} 
been concerned with the improvement of academic research library services in less developed countries. During the period 1986-1991 the specific concentration of the University Libraries Section will be on:

1. the evaluation of the effects of financial and other resource constraints on university library services;

2. the development of standards criteria for academic libraries with special reference to developing countries;

3. a study of the treatment and use of official publications in academic libraries;

4. the identification and evaluation of relevant models for the collection of university library statistics as indicators of performance;

5 . the study of managerial problems associated with the continuing acquisition and availability of research materials in the context of networks, and cooperation at the local, regional and national and/or subject level;

6. the study and evaluation of the relationship between resource sharing and local collection building;

7. the study of the relationship between preservation methods and collection development;

8. the examination of preservation programs (including the contribution of new technology) and their influence on methods of resource sharing.

While the depth of work on any one project depends on a complex international cooperation, sometimes progress is speeded by one or the other members preparing a draft document which can be amended and approved at an annual IFLA meeting as the Section's position. An example of such a draft would be "Standards for University Libraries," prepared by a Working Group led by Dr. Beverly Lynch and stressing local, analytic statements on a university library's purposes, administration, services, collections, staffing, financing, etc. If the Section's studies and positions are endorsed, they can be useful not only to a particular library, but also in efforts to move national and international bodies towards greater awareness of research library needs and purposes.

Much of the day-to-day section work falls on the shoulders of its chair, Anthony J. Loveday (SCONUL, London), and secretary, G. Gattermann (University Library, Düsseldorf). There is also a Standing Committee for the Section: from the United States, Richard Dougherty (University of Michigan), Shirley Echelman (ARL), Beverly Lynch (University of Illinois at Chicago), Peter Spyers-Duran (Wayne State), Robert Maloy (Smithsonian), and Joseph Nitecki (SUNYAlbany).

The 5lst IFLA Council and General Conference will be held at Chicago's Palmer House on August 18-24, 1985. Its theme will be "Libraries and the Universal Availability of Information." Invited speakers at the plenary sessions include Daniel J. Boorstin, U.S. Librarian of Congress; Octavio Paz, Mexican diplomat and writer; V.S. Lesokhina, U.S.S.R. Ministry of Culture; and P.B. Mangla, the University of Delhi. Simultaneous translation services will be available in English, French, German, Russian, and Spanish.

For further information, contact Robert P. Doyle, IFLA '85 Coordinator, 50 East Huron Street, Chicago, IL 60611; (312) 944-6780.

\section{Baltimore '86}

\section{A progress report on ACRL's 1986 National Conference.}

$\mathbf{T}$ he program for the Fourth ACRL National Conference, "Energies for Transition," is taking shape. Librarians in and around Charm City are setting the stage to welcome you to Baltimore April $9-12,1986$. Theme speakers will stimulate your thinking. They will include representatives from 